\title{
Artistic Practices [Between] Gender and Technologies ${ }^{*}$
}

\author{
Maia Creus Castellana \\ ESDi-Universidad Ramón Llull, Barcola, España
}

\begin{abstract}
This paper was carried out by the group of professors-Maia Creus, Tamara Díaz, and Inés Martins from the Design Analysis and Prospective Department, with the collaboration of the Catalan Institute for Women, Generalitat de Catalunya. Maia Creus and Inés Martins are parts of the research group TADD (Theory, Analysis, Design, and Development) recognized by Ramon Llull University. The research, based on feminist and performance studies, focuses on artistic groups currently working in Catalonia and whose practices produce tools and technology sharing, highlight the social and educational potential of ICTs (information and communication technologies) free access when used, consciously and critically, from feminist perspectives assumed. The research project was developed as a dual methodological process. This research group has developed a critical review of the three conceptual axes—women, art, and technology—around which revolves the present study and, in parallel, has conducted field work directly with groups of selected artists, in order to meet them within their areas of production and to know more about their working methods, theoretical discourse, goals, frustrations, and desires. This deployment in parallel was used to develop a group of key concepts that revolve around "free culture" and "culture of access" that in contrast with the practices and theories of the investigated groups are necessary to intercept and reinterpret. Through various forms of visibility, this paper intends to investigate, promote, and share these tools, technologies, and pedagogies developed by these groups which, by its own dynamics of collective work, as well as the processes of public participation, emphasize forms of interculturality and interdisciplinary.
\end{abstract}

Keywords: contemporary art, Catalonia, gender, tactical use of technology, public space, political activism, design for the 21st century

\section{Introduction}

Even though the relationship between art and technology is crucial to understand the current state of artistic practices, the center of interest of this work revolves around a very specific question: To do research on how and why, in the hands of certain women artists, ICTs (information and communication technologies) have taken giant steps, not only as creativity and production instruments, but also as a means of reflection to face new political, social, and cultural problems of our present. Our field of study is delimited to artists or artists groups, who use ICT and cybernetic space to develop collaborative practices with collective purposes and community interests. So we are talking about creativity as a political power for its will and ability to from spaces of shared and divergent interests to regular forms of sensitive experience. The artists of our research carry out one of the fundamental premises of feminist theory that we could sum up in this idea: To transform

\footnotetext{
* This investigation is still a work in progress which, to the present, has generated three diffusion documents: a speech in CIDIC 2012, the audiovisual: artistic practices [between] gender and technologies, and this paper.

Maia Creus Castellana, doctor, Unidad Departamental de Análisis y Prospectiva del Diseño, ESDi-Universidad Ramón Llull.
} 
society a critical philosophy is not enough, it is indispensable to go from theory to practical action. For the artists included in the present study, to go from thinking to action raises, among others, the following questions: (1) To what extent ICT is not a way still more subtle of alienation of new global capitalism?; (2) To what extent ICT are instruments highly subtle for an invisible technology but equally effective for the establishment of certain political technologies that allow and perpetuate relationships between knowledge and power?; and (3) To what extent the democratic use of ICT is not the new myth of the 21st century democracies?.

This critical perspective, certainly, is not circumscribed to feminist studies and practices and, however, it is the feminist perspective in the methodologies and knowledge fields which is generating a change of unknown dimensions in all spheres of current knowledge. This transforming principle is no other than a methodological change. The feminist perspective, in front of knowledge with a universality ambition, fully current in structural injustices that determine the globalization process, defend a knowledge as a basic tool that enables achieving a widen sense of objectivity and an more cross understanding of the social thing. The question raised here is as the following: Due to the fact that identities in diaspora and transnational flows of people, goods, and ideas are constituent facts of globalization, the question is determining how we can explain and take care of this spread multiplicity of hybrid subjectivities.

Due to the fact that our research has been carried out in the framework of a school of design, the author would like to stop, shortly, in noting possible relationship links between certain values of feminist theory and a culture of design for the 21st century. Design, as a complex discipline, is not reduced to principles of shape, function, market, technology, and production. On the contrary, the intellectual state of design includes determinants directly related to subsistence and dignity. From time immemorial the work of artisans, as the work of artists and architects, has been related to the civic commitment in the shared building of "polis" and "civitas". Direct heiress of this humanist conception of culture, design discipline is still a civic challenge; an aware practice of its power to transform and modify the material and immaterial realities of the world.

If we bear in mind its evolving logics and its final objectives, art and design would be two different disciplines, because they point to apparently different universes. The symbolic and expressive universe of art seems to be opposed to rational, logical, and pragmatic field of design. And, however, this feeling tends to blur to the extent that: On one hand, most of the contemporary artistic practices stop looking at art as a purpose in itself; and, on the other hand, current design immersed in are vision process of its borders, its symbolic and communicative potentials, as well as its social responsibilities in a world intervened by productivity logics.

Due to these premises, we can transpose some of the questions of feminist thinking and practice to design field: (1) From which human impulse design arises?; (2) To which interests it answers?; (3) Which are its tangible benefits and its intangible benefits?; (4) Who are the beneficiaries of the improvements that design contributes to the world?; and (5) Is it transparency or opacity the motor that impulses design industry?. If we understand design as a practice engaged to the building of "polis" and "civitas", then it shares a structural and fundamental principle of feminist thinking: to think "civitas" within the "polis" and outside it. From this conceptual framework, we may formulate the following premise: Due to the fact that feminist theory, as well as design discipline, are two activities where intellectual state is unthinkable outside direct action on world materiality, we can deduce that design and feminism are two forms of thinking in action, that point to life as a value in itself. Then again the essential questions of all the feminist thinking: What life is? Who gives life? Who has right to life? Who has the power over life? Who looks after life and how can we improve it? 
Design, art, and feminist practices converge in the humanistic concept of culture as a genuinely human power expressed in the wish to transform the reality of the world we live in. In this way, cultural products will not arise from what we "have" nor from what we "are" but from dissatisfaction, from an aware and critical reaction to distortion, contradictions, and dissatisfactions of each community and historical moment. We can say, in this sense, that art and design share the same wish to identify what would be necessary to improve human forms of life; to achieve the horizon, a "good life" for all, included life of the planet we live in. From this hypothesis, the feminist perspective, art practices and design would share the "ethical” principle of a critical and responsible position towards social purposes and consequences of our technological state of global effects. They would share the need to turn cultural productions into mechanisms able to generate more fair and relational life forms; to stimulate consensus and resistance processes to coded forms of thinking and living. To promote aesthetic attitudes showing, in the words of Rancière (2005), the "ethical turn" of certain cultural practices that are political indeed, not the exercise of power and the struggle for power but the creation of spaces for design and disagreement; to make possible new ways of thinking and make visible what is still not visible; to develop concepts and languages able to open each present in order to make possible the happening of what is new.

\section{Revision of Structural Terms of Our Research}

In our research, we share a fundamental principle of contemporary critical theory according to which, to create new realities, to create world, first you need to create new words, a new semantic. According to this idea, the cognitive processes cannot contribute great things to present consciousness if our thinking is not, in itself, creative and able to reinvent and update language through which we represent reality. The construction of a theory is able to read our present depends, in large part, on the acceptance of the performing ability of language. We know that words not only describe reality but also build it ${ }^{1}$. Our research group takes part in thoughts that today accept the performing ability of language. For this reason, we think that it is more necessary than ever to take care and a special attention in choosing and redefinition of a vocabulary appropriate to knowledge fields and work objectives. At this critical operative, the first question arisen has been to deal with a revision and updating the three words that form the structural main idea of our research, "woman”, "art”, and "technology", today subject to an intense disruption and conceptual displacement.

\section{From the Idea of Woman in Feminine to Discourse About Gender}

Several feminist critics have reaffirmed the suitability of psychoanalysis to understand in which way subjectivity and gender are formed and modeled; what is feminine and what is masculine. Identifiers model leading to identity conceived by Freud enables to understand how rules are internalized, and to show that sexual

\footnotetext{
${ }^{1}$ Performativity notion in Western thinking comes from the philosopher John Langshaw Austin with the posthumous book How to Do Things With Words (1962). One of the most innovative aspects of this English linguist is to state that the most part of our speech acts is destined to make (perform) a particular action. The idea is that, apart from stating expressions (those that can be true or false), the most part of linguistic expressions are used to do something with words, that is, to do a different act of simply saying something. From here arise realising expressions (performing) characterized by establishing a type of relationship with facts very different from the one that establish stating statements. Austin offers to us the awareness that language is an action and at the same time an instrument of our action. So language depends on a more general theory that is a theory of the action. A reference name in performing research of language is Judit Butler (2004). The author moves the performing notion to the idea of identity understood as a reflective process that takes place in language. This involves conceiving the being as a process both linguistic and collective. We are performed by language and, therefore, language is the condition of possibility of our existence. It is according to language that we become what we are every moment.
} 
and gender roles assignment is not natural but an arbitrary and cultural process regulated by dominant patriarchal trends. As Butler (1990) affirmed later on, what is feminine as what is repudiated/excluded within the system is the possibility of a criticism and the disruption of this conceptual diagram. The criticism to the idea of subject inherited from modern tradition has been one of the most important focuses of cultural and social transformation over the last years. The question about the subject, not only the feminine subject, but also the notion of subjectivity itself has been an essential point in the meeting between feminist studies and critical philosophy over the last decades of the 20th century. Feminist criticism has made visible the gender nuance implicit in the notions of reason, objectivity and universal values, always with an orientation to what is masculine. Feminist studies and practices have become one of the most active sources of transformation in dismantling of the emancipating project of the modernity implicated, we remind it, an authoritarian and universal vision from which are excluded different limit indicators: women, the others of different ethnic group or race, and natural environment.

According to these premises, the existence of the other becomes a condition of possibility of the author's identity. There is no "me as an aware reality" if we do not accept that there is an "other". The objective of feminist studies and democratic politics is to transform this "antagonism" in "conjunction", that is, to advance in accepting values and interests in conflict, or, as Foucault (1976) said, an analyses of the relationships between power and knowledge, power and sexuality. Here the notions of deconstruction and difference are fundamental. Derrida (1967a) put deconstruction within philosophy field as a knowledge method. First of all, deconstruction suggests dismantling logocentrism of cultural tradition in the West. It means a radical criticism to all possibility of an important meaning or conceptual idea or semantics as a last and absolute value. There is no metaphysical world but the continuation of textual works. There is nothing outside the text. Deconstruction means a dissemination or opening of the sense and the acceptance of a built notion of subjectivity. We become what we are exclusively for the differed action of our experiences. In feminist theories, deconstruction and criticism of the difference entailed a new wave of rewritings and revisions. Identity notion is now theorized as a difference of what is feminine in this space of differing.

More and more aware of its political and action strength focused on a performing definition of identity, cultural theory and artistic practices have worked in the proposal of non-identity models of subjectivity. In this way it is fundamental to mention Judith Butler ${ }^{2}$. The author thinks that gender and sexuality are acts, actions, and not key aspects of an essential identity. We are not of a particular gender or sexuality, but we repeatedly act according to rules ${ }^{3}$ imposed in a psychic way. Since the 1990s, expansion of this critical theory has gone still

\footnotetext{
2 The development of post-structuralist thinking was fundamental for the criticism of modern individual. The modern idea of the "individual being" as a self-aware, balanced and unitbeing is moved by the idea of individual as a contingent, dispossessed of basis and temporal being. Judith Butler, in a criticism of subjectivity within a feminist perspective, reminds that reflection from "thewoman" cannot only refer to those beings defined to this effect by the historical representation of sexual identity, but rather has to be the horizon to a criticism that identifies "sexual identity", "representation”, and "individual” as ideological impositions. See Gender Trouble: Feminism and the Subversion of Identity. New York: Routledge.

3 See Judith Butler (1993), Bodies That Matter: On the Discursive Limits of Sex. In this text, the author stated that it is the compulsory repetition of certain sexual and gender behaviors which forms the identity effects. They create the illusion of a focus of an interior and organizing gender, illusion maintained by means of a normative discourse with the aim of regulate sexuality within the compulsory framework of reproductive heterosexuality. Identity, the fact of being individual of this or that gender or sexual orientation, is present in the assigned repetition, so it is performing. Gender, therefore, is a construction that constantly hides its genesis. The construction forces us to believe in its need and naturalness; and however, this repetition is unstable and has inside the possibilities of its own subversion due to the fact that mind always fails when expressing itself. In the book Excitable Speech: A politics of Speech Act (1997), Butler moves the performing theory to social field.
} 
farer. From a critical point of view, tradition criticism is at stake, that is, which strengths and aspirations or conditions have more probability to put us aside from the inert repetition of thinking habits. In the affirmative sense, the question is determining how we can grow the political will of change and transformation, the active willing and desire of positive and creative changes.

The 21st century feminisms point to a consciousness of the privilege positions of each one, as a starting point for an understanding of the world from an ethical responsibility in front of a globalized world, where forms with which people identify—in terms of race, gender, and sexuality—keeps on conditioning personal and social relationships. The main idea carried out by new feminisms of a global world is the impossibility of the one-way vision of the world. From this perspective, Braidotti $(1991,1994)$ started an unknown concept of nomad subjectivity and moves forward to the idea of a feminist future to reach a new diagram of human subjectivity. In the development of this consciousness revolution, women have a privileged role, but they are not the only active subjects. Philosophical nomadism is based on the cartography of our historical condition that stresses the relevance of the not-unitary vision of the subject. The starting point is a critical vision of the Western ethical and the idea that individualism is the position that better fulfils the responsibility, in a cognitive and moral sense.

In Braidotti's thinking, the ethical responsibility is closely related to political awareness of positions and privileges of everyone. Consequently, the feminist ethics is interested in emotion and human passions understood as the driving force of subjectivity and not for the moral content of purpose. Feminism, among other social movements, has been extremely eloquent and innovative in the production of new views of the individual and its values. The feminist contemporary philosophy has a range of applications more general than ever. On one side, it works from a universal horizon. But feminist universalism is located, partial, and responsible ${ }^{4}$. From this perspective, the universal concept of "woman" is moved to plural "women", and to political concept of "gender".

\section{From the Idea of Art to Artistic Practices}

The question around the idea of "woman", "art", and "technology", and its inscription in the contemporary art reality cannot be separated from the two cultural revolts that have transformed contemporary art from top to bottom. We are referring to political awareness inherited from experimental tradition of historical avant-garde, and to the second wave of feminist movements and its incorporation to cultural spaces and institutions. After World War $\mathrm{II}^{5}$, the artists answer before the new social, political, and economic reality is opened out from an implacable criticism to all forms of authority, also aesthetic

${ }^{4}$ See Rosi Braidotti (2006), Transpositions: On Nomadic Ethics. Cambridge: Polity Press. Following post-structuralist thinking-Michel Foucault (1976), Julia Kristeva (1991), Jacques Derrida (1997), Massimo Cacciari (1994), and Gilles Deleuze (Deleuze Guattari, 1980), among others-Braidotti decidedly carried on with this criticism of European humanism in the new global world. Bradotti suggested a movement actively committed to social and cultural conditions defining location of everybody. The final objective is to negotiate resistance spaces against new dominant narratives of global economy. Braidotti positioned against a unit subjectivity and in favor of a nomad subjectivity which is based on a widen sense of interconnection between oneself and others, as an ethical way of resistance to contemporary neoliberal neo-conservatism.

${ }^{5}$ After 1945 and crimes against humanity, the art debate moves from the worry for the form to the research of its sense within history. This questioning has determined a fundamental change in the construction of a critical theory to inherited values. Forms that guaranteed to the author a common environment and ensured certain awareness to social link lost its pregnanceand collapsed. Philosophical generation that promulgated the "death of the man" was simultaneously anti-fascist, post-communist and post-humanist and led to repudiation the classical definition of European identity as humanist, rational, and universal. Feminist philosophies also note the European ethnocentric nature and the need of opening it to others inside and reposition diversity as a structural component of contemporary subjectivity. 
authority. In this historical context, the objective of art is to cause a radical transformation in all its languages; to block traditional forms of relationship and perception between art and its publics. Art becomes a radical laboratory. Artists made art a space from which rethinking all the inherited traditions and all the received ideas. The keywords defining this historical moment of art are "conceptualism", "community", and "consensus". This is a very known history both in Europe and the United States, and however, as Lippard (2009) had recently remembered, conceptual art history has tended to hide that conceptualisms both from north and south arose, to a large extent, from political ferment of that time that arrived relatively late to art world. The idea of art remained conceptually and intentionally related to certain ideas and aims borrowed from political-social movements of direct revolt. From this implication of art in what is common arise the first formulations of apolitical concept of art. It is in this context that along the 1960s and 1970s, the concept of "public art" ${ }^{\text {" }}$ takes shape as an answer of artists to the valid rules of an art understood as an autonomous reality separated from life surroundings.

From its origin, public art practices take position in the need of an art without frontiers and made from an ideological point of view. Public art has as starting point a criticism to aristocratic and elitist nature of museums and to the division between culture and real interests of people. From the last decades of the 20th century, artistic practices involved in the public sphere have assaulted the virtual universe as a new mechanism of political fight. Influenced by neo-Marxism, feminist theories and cultural studies, "public" options and, therefore, art "policies", try to examine and analyze the environments of private existence to understand its impact on social space. New modalities of aesthetic resistance invented by public orientation art do not depend on an expression of negativity anymore, but on creativity ${ }^{7}$. The experimental aspect of art makes a radical change towards a criticism of city spaces, urban planning, design, or architecture. The public practice of art suggests a radical conceptual change: It suggests proposals according to which life spaces are not empty and neutral, but ideological and social. In this way, space, more than a previous dimension (a place or a setting), is the result of an activity, so it is temporary, historical and symbolic ${ }^{8}$. The city is a set of identities that join in, confront, and live. The public art is interested in an analysis of the city functioning. To reveal the universal and authoritarian codes or patterns determining people's behaviors. Gender identity (masculine or feminine) is also product of an unequal distribution of existence social production responsibilities clearly benefiting masculinity. Gender values are product of the social environment (oral and body language), what is public faced up to what is private (Cortés, 2006). Cities and sexualities form and are formed by social life dynamics. Both reflect the ways in which daily life is organized, the ways in which it is represented, perceived, and understood, and the forms with which the different groups face reactions before these conditions (as cited in Cortés, 2006, p. 149).

\footnotetext{
${ }^{6}$ The current studies on public art distinguish, formally and conceptually, three notions and three paradigms of public art: art in public spaces (sculptures within the social space); art as a public space (relationships between public sculpture and location are investigated; art with public interest, which objective is to suggest a transformation of culture from the art praxis itself. This option formulates new ideas around what is public and works for a new link between art and reality.

7 These ways of thinking the art function and the artist activity dip its roots in May 68 and its verbal radicalism. From the problematic relationship between art and public and social space point of view, Guy Debord and La Internacional Situacionista continue to be indisputable points of reference. By means of its practices and texts, they tried to make visible the evident alienation of modern daily life, the all-embracing effects of advanced capitalism and its consumer dreams factory. See Ken Knabb (1991).

${ }^{8}$ As Henri Lefébvre (2000) explained: "spatial practice is dramatized thanks to potential energies of several groups return life flows to the homogeneous space of urban planning and architecture” (p. 450). La production de l'espace,Anthropos, Paris.
} 


\section{What Are We Talking About Nowadays When We Refer to the Relationship Between Art and Technology?}

In a moment in which both information processing tools and contents are accessible to all, there is the feeling that we are immersed in a boomerang effect. That is, the idea that, after claiming and exalting the democratizing and liberating potential that ICT should offer, use and social implementation policies are contributing to opposite effects is spreading and taking root $^{9}$. In a context like the current one where science and technology have become genuine mediator forms of watching, thinking, and living reality, there are many artists that choose to carry on and reinvent the assault to "show society"10 and its production conditions. Facing false social agreement—built thanks to the subjugating power of media—some artists reopen away to disagreement from art practices. The objective is a critic unfolding of prescription processes of bodies, social spaces, and human behaviors. The commitment of art with an ideology of cultural activism comes back ${ }^{11}$. The term ideology is within the art theoretical discourse to highlight the social processes through which meanings and identities are produced. This notion of ideology, which incorporates ideas from psychoanalysis and linguistics fields, does not only imply ideas and beliefs production, but the creation of identities or subjectivities with which these ideas or beliefs incarnate. Or indeed, focuses the attention on the fact that we become individuals marked by determinants of gender, race and class imposed through certain social processes determined by public and political interests. This ideological framework of an art implicated in its own historical context has been adopted as a new fighting mechanism ${ }^{12}$ in certain current artistic practices. The criticism as an idea of art does not need to place itself outside the system anymore. Its fight is the distinction and distancing as a "revolutionary index" (Deleuze \& Guattari, 1975). The idea of art is concentrated on singularity facing what is common and homogeneous, and on mapping creative practices that, without being carried out from the idea of art, can function as art.

The question around the relationship between (art-technology-society) has been formulated from a more positive and encouraging perspective by Hindu theorist Appadurai (2001). The author positively notes the fact that technological means of globalized communication societies spread identity and lifestyles scripts that later can be recreated by each one of us in new combinations of cultural meanings, imagination has get rid of its limited role in art field to be part of daily mental work of regular people. Certainly, from its entering the scene, ICTs have awakened among citizens' reactions in favor and against utopias and

\footnotetext{
${ }^{9}$ See Jesús Carrillo (2004), Arte en la red. Madrid: Cátedra. The author does not limit to depict the operative and conceptual assault of art in virtual world but he also formulates critical questions unresolved like to what extent virtual network is not a media still more subtle of cultural industry and global neoliberalism.

${ }^{10}$ This concept was launched by Guy Debourd in his well-known work: La société du spectacle (1973) (The 1994 Zone Books Edition).

${ }^{11}$ In this context, we use the widen concept of ideology as a non-unit set of social practices and representation systems with political consequences. Firstly theorized by Louis Althusser, this concept was incorporated and revised by Griselda Pollock, pioneer of gender studies and feminist theory of art. Pollock uses the concept of ideology making reference, in general terms, to processes by means of which meanings and identities are produced. See Rozsika Parker and Griselda Pollock (1987).

12 The word "mechanism" is a capital term in contemporary critical theory. It has its origin in Foucault's thinking in the middle 1970s when he began to think about problems of governability or government of men. See Michel Foucault (1994). Foucault defines the term "mechanism" as a kind of training that in a particular historical moment has had as main function to answer an emergency. In this sense, the mechanism has a predominantly strategic function. So the mechanism is always linked to the power game; to strategies of force relationships that support some types of knowledge and at the same time lean on them. Therefore, all mechanism involves a subjectivation process; embodies models of subjectivity. Giorgio Agamben has analysed the evolution of this concept in the text Che cos'è un dispositivo? (2006). Translated in: Què vol dir ser contemporani? (2008).
} 
dystopias of all kinds. But it is also true that to live in a global world stresses the possibility that image, what is imagined and the imaginary technologically influenced lead into symbolic-expressive practices that, in its hybrid and spread ordinariness, widen what before was limited to the selective framework of "high culture", to branch out in the popular world of dissemination and media consumption. From this perspective, we can wonder whether it is appropriate still to talk about art as a specific level of symbolic dimension; whether it is allowed to look in aesthetic experience for particular features in front of other discursive experiences and practices; and whether circulation forms of aesthetic products are distinguishable, although they permanently cross with other networks of cultural system. These questions have been formulated by philosopher Pau Alsina (2011) in the following way: "We can think about a balance of forces, in an authentic coproduction between technology and society, where what is technologic would be socially built to the same extent in which what is social should be considered technologically formed” (pp. 54-59). At this horizon, it is essential to have in mind certain forms of experimental art operating from the challenge of transform information technologies into technologies for empowerment ${ }^{13}$ of individuals and to promote their political power in the social space.

The invasion of 2.0 devices is substantially modifying behavior and public incidence of citizens. People in masse and habitually use collaborative tools and social networks to interact with the rest of people. These tools are modifying relationships between private and professional world. This new situation has also been critically tackled from feminist perspectives. Late postmodernism have arisen new guiding narratives. The dominant guiding discourse of neoliberal post-feminism is based on the new genetic social imaginary and marks the return of the most classical forms of economic and social discrimination. Post-feminist movement has merged with neo-conservatism in gender relationships. The dominant post-feminist narrative reintroduces the “exceptional woman” syndrome existing before women movement introduced more egalitarian principles of interconnection, solidarity and team work. As Braidotti (2006) stated, because of structural injustices determined by the globalization process, the current geopolitical situation of women is more polarized than ever. The convergence of biotechnologies and new information technologies supported by Internet is an essential factor inducing a radical revision of body policy. Foucault's work on the discursive production of contemporary embodied individuals is the backdrop appropriate for this analysis ${ }^{14}$.

Feminist scientist Dona Haraway's (1997) work also started from the supposition that, in contemporary societies, life is understood as a manipulated system. The author maintains that contemporary science has gone beyond Foucault's "bio-power" concept and is already in the "domination computing” period, that is a different regime of display and control. One of the effects of biotechnologies and genetic social imaginary is the return to discourses and practices on "real bodies". According to Rosi Braidotti (2006), techno-bodies are more

\footnotetext{
${ }^{13}$ Empowerment philosophy has its origin in popular education theories of Paulo Freire developed from the sixties. Although the concept of empowerment is applicable to all vulnerable or marginalized groups, its birth and theoretical development has been done in relation with women. From feminist point of view, empowerment of women includes both individual change and collective action, and involves theradical alteration of processes and structures that reproduce the subordinate position of female sex. Since then, the term has widened its application field. Friedman (1992) noted that empowerment is related to access to three types of powers: (1) social, understood as an access to the basis of productive wealth; (2) political, or access of individuals to the process of taking decisions, above all those that affect the own future; and (3) psychological, understood in the sense of potentiality and individual ability. In a similar way, Rowlands (1997) noted three dimensions: (1) personal, as a development of the sense of me, confidence and individual ability; (2) close relationships, as an ability to negotiate and influence nature of relationships and decisions; and (3) collective, as a participation in political structures and collective action based on cooperation.

${ }^{14}$ Michel Foucault (1986) showed that not only built structure of what we call "human nature", but also its relatively recent appearance to historical scene is what makes it coextensive with control forms and social disciplines.
} 
immersed than ever in power places, and contemporary policy is prone to massive exclusion phenomena while cyborgs are in a monetary connection not immune to racism or to traditional power relations. The renewed interest in body materiality is especially notable in contemporary feminist theory spheres combining scientific studies with references to cross subjectivity notion (Guattari, 2004) and to globalization criticism. These new feminisms recover "micro-policies" ${ }^{15}$ concept and are concentrated on the function that can carry out techno-sciences as instruments to attack advanced capitalism.

Feminist ethics exerts an important control of "diversity" policy notion, a concept transformed into very valued and marketable goods. In its commercialized form, diversity notion, Braidotti (2006) said, has increased uniformity of consumers' habits and at the same time promotes proliferation of local differences and micro-diversities. In this way, "differences" also feed markets, because what is "local" is a political space built by global flows of capital. Due to the fact that proliferation of local differences in the name of its goods condition is one of the features of global economy, globalization nourishes from otherness incorporation. So we must try not to take literally any claim of identity and cultural difference (Bradotti, 2006).

\section{Artistic Practices “Between” Gender and Technologies: When What Is Personal Is Digital}

Our research has focused on artistic practices that in a provisional and contingent way intercept "gender" and "technologies" fields. At first, our work has focused on a short cartography of artists and groups residents in Catalonia which use us electronic and digital means in their production and/or circulation processes. Due to this premise, we have preferred to allude to identity models-as could result from a research exclusively fitted to the only field of women working with new technologies-to tackle a cartography that emphasizes those practices involving collective pedagogies and alternative forms of exchange of knowledge, self-learning, and collaboration.

With the title "Artistic Practices Between Art and Technology”, we want to delimit our research work to those artistic practices made by women, for which ICT mediation in their works meet the will to create collaborative platforms of knowledge, mediation, communication, and free distribution. For this reason, we have changed the term "work" for "practices", a term that not only refers to the opening of languages, formats, and circulation channels, but also to disciplines and methodologies transversality. It puts the interest point in these intersectional spaces, on usual borders among cultural production languages, they tend to dilute. In this situation of cross of knowledge, disciplines, and ways of doing, the concept "between" that divides in two in this work title becomes the focus of maximum attention expressed in the following terms: (1) To what extent artistic practices in new media allow to answer other production of gender and identities "technologies”? And, "how" and by means of "which" processes, the selected artists actively and politically commit to fundamental questions like the idea of author, copyright, royalties, or knowledge transfer?; (2) To what extent experimentation and creativity include ethics towards free "access culture"?; and (3) To what extent feminist perspective is essential to make appear the great lie that goes with the affirmative discourse of technological progress accessible to everybody?.

When from our research, we go back to the question around the relationship between gender and

\footnotetext{
15 "What is really attractive of what is micro-political is that it makes reference to all that is part of specific cultures different from the hegemonic one; to all that aspects of daily life that normally stay hidden and that evoke practices and lives of wide sectors, that, generally, are outside historical reviews, and represent the minorities marginalized and/or condemned to silence". See José Miguel Cortés (2003).
} 
technologies, we have decided to examine the potentials of this articulation in projects questioning the conventional ways of cultural practices production and circulation. On one hand, it is about answering the hegemony of a mythologized discourse of art in terms of autonomy, originality and individual authorship, to emphasize collective projects or those that involve the participation of other social agents. On the other hand, we are interested in research, divulge, and activate initiatives suggesting the invention of spaces and tools in the articulation of new technologies and feminist practices. Notions like "pro-common", "free culture”, "do it yourself”, “free technologies”, “recycling”, “alternative economy”, “access”, and "to share knowledge” cross a large part of these efforts.

In the interviews carried out, we have investigated the specific forms with which these collective processes are formalised, the participation models showed, the more or less authoritarian or participative forms of organization; inequality in time and tasks management, difficulties and advantages of common work. In this case, we were interested in tackling collectives not only as homogeneous identities but also as formations necessarily in tension and conflict, as it is usual in the political nature of any group.

The researched practices include several formats and circulation channels that take from art field to social sciences, performance and audiovisual, music and interventions in public spaces; from activism to publications, seminars, and workshops. Precisely, the term "between" included in the title of our research puts our interest in intersections of these fields; the cross places among disciplines; and the "between" of knowledge and ways of doing. From here arises our interest in these hybrid proposals, where not only media but also circulation channels and public ones are constantly formed and modified.

One of the emphasis centers of our research has been the question about tools and technologies, the access ways that each artist has had available, and also the way of sharing them. For the most of the creators and collectives interviewed, the choice of free technologies is understood not only as a political positioning, but also as a way of sustainability of projects themselves, because it allows forms of distribution, modification, feedback, and exchange which would not be maintained in other conditions of intellectual insecurity and restricted circulation. As well, in these artists and collective works, it is important to highlight its questioning to political and ideological uses of ICT. By contrast, the juxtaposition of words "gender" and "technologies", in the title of our work, allows us to go beyond the limit of the term "technologies" beyond its usual sphere, to include it in the feminist studies discourse: Among the questions considered, we put the following question: To what extent artistic practices in new media allow to answer other "technologies" of gender and sexuality production? And, beyond this question, the question that these practices suggest is the possibility of broaden the horizon of what is common (as feminism has already done) with the inclusion of new debates and critical practices in the virtual and public space of 2.0 network.

\section{Conclusions}

In 1971, Nochlin in her foundational text, asked herself why in the history of art there has not been great women artists and also about the economic, social, and institutional structures that support the production and circulation of art. In that foundational text, Nochlin (1971) also noted that the history of art rarely investigates the conditions of production of the artwork. On the basis of this concealment, it has been founded much of the mythology of the genius. Indeed, one of the cornerstones of the conversations we shared with the artists and collectives of our research lies in the questions to their material conditions of their practices. Among other things, it has become clear that the artists, like most working women, have to manage 
their own time considering other responsibilities as the "take care" of other people, and insecurity, self-employment, moonlighting, the (un)paid work, or the possible sustainability strategies. In our question about the relationship between artistic practices, gender, and technologies, we have shown the potential of this articulation in at least seven ways.

(1) In the context of art, against the hegemony of an over-mythicised discourse in terms of autonomy, originality, and individual authorship, we want to emphasize that there exists other practices based in collaborative projects that involve the participation of other social actors.

(2) Digital technologies into the hands of many women artists, have given a crucial step in the context of certain political and social issues directly related to the "free culture" and "culture of access". Therefore, this implies to actively act in the social networks, not only to achieve its democratizing potential, but also because users can overcome the current intellectual and procedural access barriers.

(3) Technological culture has not only dramatically changed the language and purposes of art, but the paradigm of museum inherited of modernity. Today, the museum is theorized as an uncontrolled and a non-exclusion democratic place; a participative laboratory designed to create new forms of subjectivity. However, the triad museum/curator/critic is still a frontier for certain artistic practices that do not aim to the work production. Against this great force of art to produce, not only works, but cultural capital organized in borderless networks, how responds the museum of the 21st century, bearing in mind that it is still the most obvious symbol of the system of art?

(4) The women artists of our research work in various formats and channels of circulation covering the field of art, social sciences, performance, broadcasting, music, and interventions in public spaces; from activism to the publications, seminars, and workshops. In this sense, we note that the term "between" included in the title of our research, situates our interest in the intersections, in the crossing between disciplines. Therefore, the "between" of knowledge and ways of doing things.

(5) On the relationship between art and technology, we have been interested into highlighting how some women artists experiment with "political" intention, the "dissident uses of technology". This "diverted" use, allows the emergence of other and different narratives such as, the deliberate use of noise and low resolution, and to emphasize the negative side of the equation (trial/error) as ironic vindication of the right and freedom to err.

(6) The juxtaposition of the words "gender" and "technology" has enabled us to exceed the usual limits of the concept of "authorship", nowadays diluted into ways of collective and collaborative work, and the one of "work of art", dematerialized with practices that do not generate objects to be exhibited, but to share experiences and knowledge. In this regard, we remark that the women artists of our research include the "technology" beyond their usual sphere, to enroll it in the feminist discourse of the "technologies of the self" in the bio-political sense described by Foucault and Butler.

(7) Finally, we want to emphasize that the "ethic" and "politic" dimension situate the artistic practices of our research in the stage of feminist theory of the 21st century. In this context, we talk about artists who advocate an idea of plural or nomadic subjectivity following Rossi Braidotti's thought. The hope of this new feminism, beyond a policy of resistance, is to move towards a form of nomadic identity in favor of plurality and difference. Against universalism, nomadic subjectivity orients to groups and specific contexts and takes life as a subject of political discourse. 


\section{References}

Agamben, G. (2006). Che cos’è un dispositivo?. Què vol dir ser contemporani?. Barcelona: Arcàdia- La Central.

Alsina, P. (2011). Tratado de dermatología general o cuando la visión se vuelve háptica. Quadern de les Arts, les Lletres i les Idees, 181, 54-59.

Appadurai, A. (2001). La modernidad desbordada: Dimensiones culturales de la globalización. Montevideo: Trilce.

Braidotti, R. (1991, 1996). Patterns of dissonance: An essay on women in contemporary French philosophy. Cambridge, USA: Routledge.

Braidotti, R. (1994). Nomadic subjects: Embodiment and sexual difference in contemporary feminist theory. Cambridge: Columbia University Press.

Braidotti, R. (2006). Transpositions: On nomadic ethic. Cambridge: Polity Press.

Butler, J. (1990). Gender trouble: Feminism and the subversion of identity. New York: Routledge.

Butler, J. (1993). Bodies that matter: On the discursive limits of sex. New York: Routledge

Carrillo, J. (2004). Arte en la red. Madrid: Cátedra.

Certeau, M. (1993). l'Invention du Quotidien (Vol. 1). Paris: Gallimard.

Cortés, J. M. (2003). Micropolíticas, la culminación de un proyecto. Micropolíticas, arte y cotidianidad 2001-1968 (catalogue). EACC-Espai d'Art Contemporani de Castelló, València.

Cortés, J. M. (2006). Políticas del espacio: Arquitectura, género y control social. Barcelona: Actar.

De Lauretis, T. (1987). Technologies of gender: Essays on theory, film, and fiction. Indiana: Indiana UniversityPress.

Deleuze, G. (1968). Diferencia y repetición. Gijón: Júcar Universidad.

Deleuze, G., \& Guattari, F. (1975). Kafka, pour une littérature mineure. Paris: Minuit.

Derrida, J. (1967a). De la grammatologie. Paris: Minuit

Derrida, J. (1967b). La escritura y la diferencia. Barcelona: Anthropos.

Foucault, M. (1975). Vigilar y castigar. Madrid Siglo, XXI.

Foucault, M. (1976). Historia de la sexualidad (Vol. I). Madrid: Siglo XXI.

Foucault, M. (1994). Dits et écrits (Vol. III, pp. 299-300). Paris: Éditions Gallimard.

Knopp, L. (2006). Sexuality and urban Space. In D. Bell \& G. Valentine (Eds.), Mapping desire (p. 149). London: Routledge.

Langshaw Austin, J. (1962). How to do things with words. London: Oxford University Press.

Lippard, L. (2009). Hagámoslo nosotros mismos. Ideas recibidas, un vocabulario para la cultura artística contemporánea (pp. 34-50). Barcelona: MACBA.

Nochlin, L. (1971, January). Why have there been no great women artists?. ART News.

Parker, R., \& Pollock, G. (1987). Feminism and modernism. Framing feminism, art and the women's movement, $1970-1985$. London and New York: Pandora Press.

Pickering, A., \& Guzik, K. (1995). The mangle in practice: Science, society, and becoming. New York: Duke University.

Preciado, B. (2008). Testo Yonqui. Madrid: Espasa Calpe.

Rancière, J. (2005). Sobre políticas estéticas. Barcelona: MACBA, UAB.

Rheingold, H. (2004). Multitudes inteligentes: La próxima revolución social. Barcelona: Gedisa.

Schechner, R. (1988). Performance theory. New York: Routledge.

Witti, M. (1992). The straight mind and other essays. Boston: Beacon Press. 